Lingua Rima: Jurnal Pendidikan Bahasa dan Sastra Indonesia

Vol. 10 No. 2 Juli 2021

http://jurnal.umt.ac.id/index.php//grm

\title{
NILAI-NILAI SOSIAL DALAM DWILOGI NOVEL SEPASANG YANG MELAWAN KARYA JAZULI IMAM (PENDEKATAN SOSIOLOGI SASTRA)
}

\author{
Shifa Fauziah ${ }^{1}$, \\ Universitas Muhammadiyah Prof. Dr. HAMKA \\ shifaf69@gmail.com \\ Trie Utari Dewi ${ }^{2}$ \\ Universitas Muhammadiyah Prof. Dr. HAMKA \\ email: trie.utari.dewi@uhamka.ac.id
}

\begin{abstract}
ABSTRAK
Dwilogi Novel Sepasang yang Melawan karya Jazuli Imam menceritakan tokoh yang memiliki jiwa sosial tinggi baik terhadap sesama manusia maupun alam semesta. Tujuan penelitian ini adalah mendeskripsikan nilai-nilai sosial yang terdapat dalam Dwilogi Novel Sepasang yang Melawan karya Jazuli Imam. Penelitian ini menggunakan pendekatan sosiologi sastra. Metode penelitian yang digunakan adalah metode kualitatif deskriptif. Objek penelitian ini adalah nilai-nilai sosial dalam Dwilogi Novel Sepasang yang Melawan karya Jazuli Imam yang diterbitkan oleh penerbit Djelajah Pustaka tahun 2014 dan 2017. Teknik pengumpulan data dalam penelitian ini adalah teknik simak dan catat. Teknik analisis menggunakan metode deskriptif analisis. Hasil temuan dalam analisis nilai-nilai sosial dalam Dwilogi Novel Sepasang yang Melawan yaitu pengabdian, tolong-menolong, kekeluargaan, kesetiaan, kepedulian, nilai rasa memiliki, disiplin, empati, nilai keadilan, toleransi, kerjasama, dan demokrasi. Pada Dwilogi Novel Sepasang yang Melawan karya Jazuli Imam nilai sosial yang dominan yaitu nilai kepedulian.
\end{abstract}

Kata kunci: Nilai sosial, Dwilogi, Sosiologi Sastra

\section{A. PENDAHULUAN}

Manusia merupakan makhluk sosial yang hidup berdampingan dan saling membutuhkan. Manusia saling berinteraksi, gotong royong, dan menghargai antar sesama. Menurut ilmu sastra, hal tersebut menjadi kajian ilmu sastra yaitu sosiologi sastra. Kajian sosiologi sastra, berasumsu bahwa karya sastra dapat dihubungkan dengan kenyataan. Karya sastra dianggap sebagai cerminan kenyataan kehidupan nyata yang tertuang dalam karya sastra. Oleh karena itu, harus dipahami dan dihubungkan dengan segi-segi kemasyarakatan. Dengan begitu, keterlibatan pengarang dalam merepresentasikan realitas sosial dalam karya sastra dapat dilihat melalui tokoh yang diciptakan oleh pengarang itu sendiri. Karya sastra sebagai manifestasi kehidupan yang mana banyak menampilkan persoalan yang perlu dikritisi dan dipahami secara mendalam. Di samping itu, karya sastra juga dapat menjadi sarana 


\section{Lingua Rima: Jurnal Pendidikan Bahasa dan Sastra Indonesia \\ Vol. 10 No. 2 Juli 2021 \\ http://jurnal.umt.ac.id/index.php/lgrm}

penyampaian nilai-nilai ataupun ideologi tertentu pada masyarakat pembaca. Salah satu nilai yang terkandung dalam karya sastra adalah nilai-nilai sosial.

Karya sastra modern yang mengacu pada realitas dalam menyampaikan pesan dengan nilai-nilai sosial adalah novel. Pendapat Solihati, Hikmat dan Hidayatullah. (2016:97) bahwa novel merupakan karya prosa dalam menyampaikan alur dan penokohannya tidak mementingkan rima, metrum, dan irama. Dengan begitu hal ini tidak membuat keestetikan novel berkurang, melainkan novel memiliki estetika sendiri melalui susunan imajinasi yang dibangun dari pikiran pembaca. Nilai sosial yang terdapat dalam novel biasanya ditampilkan secara implisit dan eksplisit sehingga pembaca dapat menyimpulkan sendiri nilai-nilai tersebut dan dapat diaplikasikan pada kehidupan nyata. Novel Sepasang yang Melawan 1 dan Sepasang yang Melawan 2 merupakan sebuah dwilogi karya Jazuli Imam. Jazuli imam adalah seorang penulis naskah teater dan juga novelis berkebangsaan Indonesia yang lahir di Klaten pada 3 Januari 1990. Novel pertama yang ia ciptakan adalah Pejalan Anarki yang sekarang berubah judul menjadi Sepasang yang Melawan 1. Karya sastra yang ia tulis memiliki ciri khas yaitu merceritakan tentang kemanusiaan dan kebebasan alam.

Dwilogi Novel Sepasang yang Melawan karya Jazuli Imam mengangkat kisah tentang romantika perjuangan cinta dari dua anak muda yang berpikir idealis melawan realita yang menghujam sistem masyarakat. Novel ini juga berlatarkan cerita tentang kehidupan di daerah terpencil Nusantara yaitu distrik Noari bagian Selatan Papua. Di mana pada daerah tersebut diceritakan bahwa adanya beberapa tokoh yang menentang keras pemerintah. Sikap menentang dari beberapa tokoh dalam novel tersebut mencerminkan bentuk kepedulian sosial, yaitu salah satunya sikap tokoh yang tidak setuju dengan bantuan pemerintah terhadap masyarakat Noari Papua. Tokoh dalam cerita tersebut menentang pemerintah untuk memberikan bantuan pendidikan berupa seragam dan sepatu sekolah. Tokoh tersebut menganggap bahwa hal ini akan menjadi bumerang untuk anak-anak distrik Noari Papua, karena ia menganggp bahwa anak-anak yang bersekolah tidak membutuhkan barang-barang tersebut, yang anak butuhkan hanyalah buku-buku. Hal ini dianggap karena jika anak-anak diberi bantuan berupa seragam dan sepatu, terdapat kesenjangan sosial, karena jika sepatu itu rusak anak-anak akan meminta sepatu yang baru kepada orang tuanya atau malah anak-anak tidak ingin sekolah dan malu menggunakan sepatu yang rusak itu. Maka dari itu, novel ini menjelaskan bagaimana pentingnya perduli terhadap sesama, hubungan kekeluargaan, mengasihi, juga melawan ketidakadilan.

Nilai-Nilai Sosial dalam Dwilogi Novel Sepasang yang Melawan Karya Jazuli Imam (Pendekatan Sosiologi Sastra) 


\section{Lingua Rima: Jurnal Pendidikan Bahasa dan Sastra Indonesia \\ Vol. 10 No. 2 Juli 2021 \\ http://jurnal.umt.ac.id/index.php/lgrm}

Penelitian terhadap Dwilogi Novel Sepasang yang Melawan dirasa sangat penting untuk dilakukan, karena novel tersebut sarat akan kritik sosial yang menghasilkan nilai-nilai sosial yang dapat mempengaruhi pembaca. Selain itu, Dwilogi Novel Sepasang yang Melawan Karya Jazuli Imam sangat populer dikalangan pecinta alam. Oleh karena itu, dwilogi novel ini dapat mengajarkan banyak makna, tujuan hidup, kemanusiaan, dan kealam-bebasan. Adapun, tujuan penelitian ini adalah untuk mengetahui dan menganalisis tipe nilai-nilai sosial yang terdapat dalam Dwilogi Novel Sepasang yang Melawan karya Jazuli Imam dengan mengarahkan pada teori Zubaedi (2007:13) yang mengemukakan bahwa nilai sosial terdiri atas beberapa sub nilai yaitu: (1) loves (kasih sayang) yang terdiri atas pengabdian, tolongmenolong, kekeluargaan, kesetiaan, dan kepedulian; (2) responsibility (tanggung jawab) antara lain nilai rasa memiliki, disiplin, dan empati; (3) life harmony (keserasian hidup) yang terdiri atas nilai keadilan, toleransi, kerjasama, dan demokrasi.

Salah pendekatan yang sesuai untuk meneliti Dwilogi Novel Sepasang yang Melawan karya Jazuli Imam yaitu menggunakan pendekatan sosiologi sastra. Pendekatan sosiologi sastra terdapat tiga perspektif. Pertama, perspektif teks sastra, artinya peneliti menganalisis sebagai sebuah refleksi kehidupan masyarakat dan sebaliknya. Kedua, perspektif biografis, yaitu peneliti menganalisis pengarang. Ketiga, perspektif reseptif, yaitu penelitian menganalisis penerimaan masyarakat terhadap teks sastra (Endraswara dalam Irma, 2017:2). Pendekatan sosiologi sastra ini menyimpan perhatian pada aspek dokumenter sastra, dengan alasan bahwa sastra merupakan gambaran fenomena sosial. Pada hakikatnya, fenomena sosial itu bersifat konkret, sering kali terjadi di sekeliling kita sehari-hari, dapat diobservasi, dan didokumentasikan. Dalam pengamatan pengarang, fenomena tersebut dapat diangkat menjadi cerita dalam bentuk karya sastra (Nasution, 2016:17). Maka dari itu, karya sastra diciptakan untuk dinikmati pembaca, dipahami, dan dimanfaatkan oleh masyarakat.

Salah satu analisis menggunakan pendekatan sosiologi sastra yaitu menganalisis nilai sosial. Nilai sosial merupakan nilai yang dilakukan dengan cara bermusyawarah dengan masyarakat atau sekelompok orang untuk menyelesaikan suatu masalah dan mencari solusi dalam permasalahan tersebut (Trisnawati, 2018:18). Menurut Zubaedi (2007:12) nilai-nilai sosial merupakan seperangkat sikap individu yang dihargai sebagai suatu kebenaran dan dijadikan standar bertingkah laku guna memeroleh kehidupan masyarakat yang demokratis dan harmonis. Nilai sosial tentunya harus dimiliki masyarakat juga diamalkannya. Menurut Oktaviyanti (2016:114) jika masyarakat tidak mengamalkan nilai sosial maka disintegrasi Nilai-Nilai Sosial dalam Dwilogi Novel Sepasang yang Melawan Karya Jazuli Imam (Pendekatan Sosiologi Sastra) 


\section{Lingua Rima: Jurnal Pendidikan Bahasa dan Sastra Indonesia \\ Vol. 10 No. 2 Juli 2021 \\ http://jurnal.umt.ac.id/index.php//grm}

dalam masyarakat akan terjadi. Seperti halnya anak-anak yang bertindak tidak sesuai nilai sosial, maka akan tercipta perilaku sosial yang kurang baik.

Penelitian terdahulu terkait nilai sosial adalah penelitian yang pernah dilakukan oleh Saputra, Atmazaki dan Abdurahman (2012) dalam Jurnal Pendidikan Bahasa dan Sastra Indonesia Universitas Negeri Padang, yang meneliti "Nilai-Nilai Sosial Dalam Novel Bukan Pasar Malam Karya Pramoedya Ananta Toer”. Pada penelitiannya terdapat nilai-nilai sosial yang diperoleh yaitu, tolong-menolong, kasih sayang, toleransi, kepedulian, dan kebersamaan. Adapun penelitian serupa tentang nilai-nilai sosial yang dilakukan oleh Cahyani \& Rahmayanti (2020) dalam Jurnal Stilistika STKIP PGRI Banjarmasin yang berjudul "NilaiNilai Sosial dalam Novel Untukmu Imam Rahasiaku Karya Maylan Kokonoka” dalam penelitian jurnalnya beliau mengambil tiga tipe nilai sosial yaitu nilai agama, nilai moral, dan nilai pendidikan. Berdasarkan penelitian sebelumnya, peneliti tertarik untuk melakukan penelitian mengenai nilai sosial. Oleh karena itu, tujuan dalam penelitian ini yaitu menganalisis dan mendeskripsikan nilai-nilai sosial dalam Dwilogi Novel Sepasang yang Melawan karya Jazuli Imam menggunakan pendekatan sosiologi sastra.

\section{B. METODE PENELITIAN}

Jenis penelitian dalam penelitian ini yaitu penelitian kualitatif dengan metode penelitian menggunakan deskriptif analitis. Penelitian ini menggunakan pendekatan sosiologi sastra. Sumber data penelitian ini yaitu Dwilogi novel Sepasang yang Melawan karya Jazuli Imam. Novel Sepasang yang Melawan 1 ini berjumlah 415 halaman yang diterbitkan oleh Djelajah Pustaka pada tahun 2014 cetakan ke-6 dan Novel Sepasang yang Melawan 2 berjumlah 303 halaman yang diterbitkan oleh Djelajah Pustaka pada tahun 2017 cetakan ke-3. Data dalam penelitian ini yaitu kutipan teks Dwilogi novel Sepasang yang Melawan karya Jazuli Imam yang berkaitan dengan nilai sosial. Data diperoleh melalui teknik simak dan catat, data yang dihasilkan berupa kata-kata, kalimat, dan paragraf yang mengandung nilai-nilai sosial. Teknik analisis isi dalam penelitian ini dilakukan dengan membaca, menandai, menganalisis Dwilogi Novel Sepasang yang Melawan Karya Jazuli Imam berdasarkan konsep pendekatan sosiologi sastra teori Zubaedi untuk memperoleh nilai sosial secara utuh, menguji keabsahan data menggunakan triangulasi, dan menarik kesimpulan.

\section{HASIL DAN PEMBAHASAN}

Pada Dwilogi Novel Sepasang yang Melawan Karya Jazuli Imam terdapat pesan-pesan yang ingin disampaikan oleh pengarang dalam karyanya, salah satunya adalah nilai sosial Nilai-Nilai Sosial dalam Dwilogi Novel Sepasang yang Melawan Karya Jazuli Imam (Pendekatan Sosiologi Sastra) 


\section{Lingua Rima: Jurnal Pendidikan Bahasa dan Sastra Indonesia \\ Vol. 10 No. 2 Juli 2021 \\ http://jurnal.umt.ac.id/index.php//grm}

yang bersifat mendidik mengenai kehidupan, kemanusiaan, kealam-bebasan, dan lain sebagainya. Berdasarkan hasil penelitian, maka terdapat tiga nilai sosial yang termuat dalam Dwilogi Novel Sepasang yang Melawan Karya Jazuli Imam, hasil temuan penelitian sebagai berikut: 1) Nilai kasih sayang antara lain, (a) pengabdian sebanyak 3 temuan, (b) tolongmenolong sebanyak 4 temuan, (c) kekeluargaan sebanyak 5 temuan, kesetiaan sebanyak 4 temuan, dan kepedulian sebanyak 6 temuan. (2) Nilai tanggung jawab antara lain, (a) nilai rasa memiliki sebanyak 2 temuan, (b) disiplin sebanyak 1 temuan, dan (c) empati sebanyak 3 temuan. 3) Nilai keserasian hidup antara lain, (a) nilai keadilan sebanyak 3 temuan, toleransi sebanyak 2 temuan, kerjasama sebanyak 4 temuan, dan demokrasi sebanyak 1 temuan.

1. Nilai Kasih Sayang

a. Pengabdian

Bentuk pengabdian dapat dilakukan dengan cara apapun dan di mana saja. Termasuk pada zaman sekarang bentuk pengabdian masih dijalankan oleh masyarakat untuk menyebarkan nilai kebaikan, dan memberikan keuntungan bagi masyarakat luas. Dalam Dwilogi Novel ini, nilai pengabdian dapat dibuktikan dengan kutipan sebagai berikut.

“...El dan Sekar bergerak keliling membagikan sticker kecil bergambar logo buang sampah pada tempatnya untuk ditempel para penjual makanan dan minuman yang memakai kemasan sekali pakai."'(SYM 1:275)

Kutipan di atas diambil dari cerita novel Sepasang yang Melawan 1, menggambarkan bagaimana El dan Sekar melayani masyarakat dengan tindakan yang mereka lakukan demi kebaikan masyarakat dan lingkungan alam sekitar. Keuntungan bagi masyarakat dengan tindakan El dan Sekar adalah masyarakat dapat menikmati lingkungan yang sehat dan bersih, sedangkan bagi lingkungan alam tindakan tersebut dapat mencegah kerusakan ekosistem.

“...Papua pada dasarnya adalah bukan lagi sesuatu yang baru bagi Eliza. Sebelum Noari, Eliza telah lebih dahulu berada selama setahun di pegunungan tengah, Wamena..'(SYM 2:160)

Kutipan di atas menunjukkan nilai pengabdian yang dilakukan oleh Eliza di tanah Papua untuk menjadi seorang tenaga pendidik. Sikap yang ditunjukkan Eliza ini adalah sebuah pengadian yang tulus ia lakukan untuk mencerdaskan anak-anak di Papua.

“...Jauh sebelum Eliza datang, seorang pejalan bernama Lana hadir di kampung Noari. Lana adalah seorang pemuda pendatang yang kini tidak bisa dipisahkan dari anak-anak juga warga kampung Noari. '”(SYM 2:169) 


\section{Lingua Rima: Jurnal Pendidikan Bahasa dan Sastra Indonesia \\ Vol. 10 No. 2 Juli 2021 \\ http://jurnal.umt.ac.id/index.php/lgrm}

Dilihat dari kutipan di atas, jelas bahwa Lana mengabdikan dirinya kepada anakanak dan warga Noari, untuk dapat memberikan nilai-nilai kebaikan, mengajar anak-anak dalam mengapresiasi keindahan alam.

b. Tolong-menolong

Sikap tolong-menolong sebetulnya sangat penting bagi siapapun, karena pada dasarnya manusia ini saling membutuhkan pertolongan. Sebagai makhluk sosial yang beriman maka menolong sesama manusia yang dalam keadaan sulit adalah wajib. Maka, itulah pentingnya hidup bermasyarakat saling membutuhkan dan melengkapi satu sama lain. Di dalam Dwilogi Novel Sepasang yang Melawan nilai tolong-menolong dapat dilihat dari perbuatan tokoh- tokoh di dalamnya, dapat dibuktikan dengan beberapa kutipan berikut:

“...Rama yang memang seorang dari kalangan yang berkecukupan, berinisiatif untuk memberikan uang kepada keluarga Sekar seolah-olah itu adalah kiriman dari Sekar"'(SYM 1: 366-367)

Kutipan di atas diambil dari novel Sepasang yang Melawan 1 yang menggambarkan nilai tolong-menolong. Sikap Rama dalam kutipan tersebut membantu Sekar dan El dengan cara mengarang cerita kepada keluarga Sekar. Rama mengaku kepada keluarga Sekar bahwa ATM yang dipakai Sekar sedang bermasalah. Itulah yang Rama lalukan selama dua bulan ini untuk menenangkan keluarga Sekar agar rencana pelarian El dan Sekar tidak dicurigai.

“...Non, kata El di muka pintu. "Kamu buka baju. Semua. Telanjang. Kamu masuk ke sleeping bag Dara. Tutup. Peluk dara. Sambil terus tepuk-tepuk pipinya dan diajak ngorol ya. Yah Ngerti kan sayang?"(SYM 2:55)

Kutipan di atas diambil dari novel Sepasang yang Melawan 2 yang menggambarkan nilai tolong-menolong yang dilakukan oleh El dan Sekar atas kejadian hipotermia yang dialami tokoh Dara saat berada di Gunung Gede Pangrango. El dan Sekar menyelamatkan nyawa Dara dengan tindakan seperti yang ada pada kutipan di atas.

“... E eh, Sekar,” Rangga menarik gas motornya saat Sekar sudah berjalan tiga-empat langkah didepannya. "Bareng aja," katanya lagi. (SYM 2:103)

Kutipan di atas menjelaskan bagaimana sikap menolong Rangga kepada Sekar. Dalam kisahnya mereka baru saja berkenalan, maka tidak menutup kemungkinan dalam 


\section{Lingua Rima: Jurnal Pendidikan Bahasa dan Sastra Indonesia \\ Vol. 10 No. 2 Juli 2021 \\ http://jurnal.umt.ac.id/index.php/lgrm}

dunia pendaki sikap tolong-menolong sudah menjadi budaya. Rangga membantu Sekar karena ia melihat Sekar berjalan sendirian menuju basecamp pendakian Gunung Merbabu “...Eliza menerima kaos yang diberikan Mama. Hanya, ketika Eliza ingin membayarnya, Mama itu menolak. Bapak yang sedang menggendong anak mereka juga menolak."

"Sudah Mama, begini saja. Ini kaos saya ambil. Tapi saya juga titip. Nanti di kota kan ada yang jual buku to. Nah, ini saya minta tolong Mama belikan” kata Eliza pada Mama. (SYM 2:185)

Kutipan di atas menggambarkan sikap tolong-menolong sesama manusia. Eliza yang sudah banyak membantu di tanah Papua mendapatkan balas budi dari Mace Pace dengan diberikannya kaos. Bukti bahwa seseorang yang melakukan kebaikan pasti dibalas dengan kebaikan pula.

c. Kekeluargaan

Nilai kekeluargaan dalam Dwilogi Novel Sepasang yang Melawan banyak ditemukan pada orang-orang terdekat yang dianggap seperti layaknya keluarga. Hal ini dapat dibuktikan dengan kutipan berikut:

“...Pak, ayo anak-anak diajak makan. Sudah siap,” kata ibuk yang baru saja datang menghampiri El, Sekar, dan Pak Masrum. ”(SYM 2:172)

Kutipan di atas diambil dari novel Sepasang yang Melawan 1 yang menggambarkan bentuk kekeluargaan yang dilakukan oleh keluarga Pak Masrum kepada El, hal tersebut terjadi karena $\mathrm{El}$ adalah sosok orang yang friendly dan sopan kepada orang yang sangat berjasa bagi dirinya. Maka dari itu, sambutan baik keluarga Pak Masrum seakan menganggap bahwa El adalah sosok putranya.

“...Siang hari itu juga setelah tiket kereta sudah ada di tangannya, El mengantarkan kekasihnya yang bersedih hati itu ke stasiun untuk pulang ke Bandung melihat Ayahnya yang sedang sakit."'(SYM 1:305)

Kutipan di atas diambil dari novel Sepasang yang Melawan 1 yang menggambarkan nilai kekeluargaan dan bentuk kasih sayang Sekar kepada Ayahnya.

“...Banyak yang nawarin kerja. Ada lah. Yang jelas aku harus dapat pemasukan buat nutup keperluan rumah. Paling tidak sampai nanti Ibu pulih dan bisa kerja lagi," Sekar menjelaskan. (SYM 1:314)

Kutipan di atas diambil dari novel Sepasang yang Melawan 1, menggambarkan nilai kekeluargaan. Di mana Sekar rela mengorbankan kuliah semester akhirnya untuk membantu perekonomian keluarga dengan cara bekerja. 


\section{Lingua Rima: Jurnal Pendidikan Bahasa dan Sastra Indonesia \\ Vol. 10 No. 2 Juli 2021 \\ http://jurnal.umt.ac.id/index.php/lgrm}

“...Sekar baru menyadari bahwa tanpa sepengetahuannya, sebelum ia berangkat, Ayah memperbaiki kerusakan-kerusakan di jaket Sekar. Ayah menjahitnya dengan tangan sendiri. Bayangan tentang laki-laki sekeras Ayah menarikkan jarum jahit dengan tangannya, sunggu itu menusuk ke dalam. Air mata Sekar menetes. ’(SYM 2:31)

Kutipan di atas menggambarkan nilai kekeluargaan, yang mana seorang ayah yang sangat menyayangi anak perempuannya, walaupun ayah Sekar terbilang sangat dingin perilakunya terhadap Sekar, tetapi di sisi lain ayah Sekar sangat menyayangi Sekar.

“...Ia memasak lebih dari tiga porsi, satu untuknya, satu untuk Bayu, dan sisanya akan ia berikan kepada pendaki lain yang mendirikn tenda di Pasar Bubrah.” (SYM 2:120)

Kutipan di atas menunjukkan sikap Sekar yang berhati mulia. Sekar tidak mengenali pendaki dari mapala UGM sebelumnya, tetapi sikap ia seperti orang yang sudah mengenal dekat. Dari kutipan di atas, menggambarkan bentuk nilai kekeluargaan sesama pendaki walaupun tidak mengenalnya.

\section{d. Kesetiaan}

Nilai kesetiaan biasanya tertuang kepada seseorang terdekat kita seperti keluarga, sahabat, dan kekasih. Dalam nilai kesetiaan mengandung aspek seperti, kebersamaan dan solidaritas. Berikut adalah data nilai kesetiaan dalam Dwilogi Novel Sepasang yang Melawan.

"Telebih kemarin sore, sepulang dari Api Purba sehabis melepas burung Jalak Suren, vespa El mogok di tengah jalan, tak lama pengendara vespa lain datang menghampiri menawarkan sebuah busi untuk El."(SYM 1: 166)

Kutipan di atas diambil dari novel Sepasang yang Melawan 1, yang menggambarkan sikap solidaritas persaudaraan komunitas vespa, yang mana bahwa hal ini menyangkut tentang persaudaraan yang lebih dari sekedar jargon, komunitas ini tidak mengenal tua, muda, pria, dan wanita, jika mereka bervespa maka mereka bersaudara. Maka, dari kutipan di atas hal tersebut menjadi nilai sosial yang termasuk nilai kesetiaan.

"Sekar sangat bahagia. Matanya menggenang haru. Ia tidak bisa bicara apa-apa lagi sesudah itu. Ia sangat bahagia. Di hadapannya, Rama, seorang laki-laki yang sejak kecil berada bersamanya, menyukainya, dan terus berbuat apa-apa untuk membuat Sekar bahagia."'(SYM 2:14)

Kutipan di atas menggambarkan nilai kesetiaan. Di mana nilai kesetiaan yang ditunjukkan tokoh Rama ini menunjukkan kebersamaan yang dilalui sejak kecil sebagai bentuk kesetiaan. 


\section{Lingua Rima: Jurnal Pendidikan Bahasa dan Sastra Indonesia \\ Vol. 10 No. 2 Juli 2021 \\ http://jurnal.umt.ac.id/index.php/lgrm}

“...di halaman ia disambut para murid. Begitu setiap hari. Para murid selalu berdiri di halaman menunggu Eliza. Begitu Eliza terlihat oleh mereka, murid-murid itu berhamburan menyalami dan berebutan membawakan tas jinjing guru kesayangan mereka itu; Eliza Puteri.'(SYM 2:186)

Kutipan diatas menggambarkan betapa beruntungnya menjadi ibu guru Eliza, yang mengajar anak-anak distrik Noari. Ia mengajar dilingkungan orang-orang yang sangat menyayangi dirinya. Yakni anak-anak selalu setia menyambut kedatangan Eliza di kelas mereka, dan berebutan untuk membawakan tas yang dikenakan Eliza.

“..Ini bukan perbuatanku, El. Ini perbuatan semesta. Dan perempuan ini. Aku..”Sekar menahan kata-katanya lantas menolehkan kepalanya menghadapi El. "Aku adalah apa yang telah engkau jadikan. Jalanku adalah jalanmu, jalan yang engkau bukakan. Keberanianku adalah keberanianmu. Cintaku adalah cintamu. Kedatanganku adalah kedatanganmu." (SYM 2: 264)

Kutipan di atas menggambarkan bertemunya kembali sepasang kekasih Sekar dan El setelah lama berpisah. Rasa yang mereka miliki masih sama seperti dahulu mereka bersama.

e. Kepedulian

Di dalam Dwilogi Novel Sepasang yang Melawan pengarang banyak menceritakan tokoh yang berperilaku baik yang peduli terhadap sesama manusia. Dalam hal ini rasa kepedulian didapatkan dari tokoh-tokoh dalam cerita. Hal ini dapat dibuktikan dengan kutipan berikut:

"...Menerima kabar dari El. Pejoh, Kencing, dan Mas Dewo, datang bersamaan dari Jogja ke Surabaya menjenguk Sekar."(SYM 1:366)

Kutipan di atas diambil dari novel Sepasang yang Melawan 1 yang menggambarkan bentuk kepedulian Pejoh, Kencing, dan Mas Dewo terhadap Sekar, mereka kasihan terdahap Sekar yang sedang sakit dan tidak memiliki orang terdekat selain El saat ia berada di Surabaya. Hal ini menunjukan sikap Pejoh, Kencing, dan Mas Dewo sebagai seorang sahabat yang memiliki rasa kepedulian terhadap sahabatnya yang sedang mengalami musibah.

“...Semakin lama kereta semakin penuh. Bermacam-macam penumpang berdatangan. Kursi-kursi sudah penuh, termasuk kursi di sebelah El dan Sekar. Di dekat mereka ada dua orang ibu-ibu berdiri. El membangkitkan tubuhnya dan mempersilahkan satu ibu untuk duduk ditempatnya, tak disangka Sekar mengikuti El, ia pun berdiri dan memberikan kursinya kepada ibu yang satunya." (SYM 2:40) 
Kutipan di atas, menggambarkan betapa pedulinya El dan Sekar terhadap ibu-ibu yang tidak mendapati kursi di kereta yang mereka tumpangi. Sikap yang mereka miliki adalah mementingkan kepentingan orang yang lebih membutuhkan.

“...Berhasil El dan Sekar dapat membaurkan diri ke pengamen, yang ternyata setelah diajak berkenalan memang tidak ada alasan untuk Sekar takut kepadanya. El dan Sekar mengeluarkan beberapa bekalnya untuk dibagi dan dinikmati bersama pengamen itu. ’(SYM 2:42)

Kutipan di atas menggambarkan El dan Sekar yang sungguh-sungguh ingin berbaur dengan pengamen yang berada di kereta itu. Hal ini menunjukkan sikap El dan Sekar sebagai masyarakat sosial yang memiliki rasa peduli terhadap seseorang tanpa melihat cover diri pengamen itu sendiri.

"...pengamen itu pamit untuk tidur dan meminta tolong untuk dibangunkan di Stasiun Cikampek. El dan Sekar sangat senang dan tentu bersedia melakukan itu. Sepasang itu menggeser letak duduknya untuk memberi ruang pada si pengamen menyelonjorkan kakinya dan beristirahat tidur. "(SYM 2:43)

Kutipan di atas menunjukan nilai kepedulian yang dimiliki sepasang kekasih itu. Ditunjukkan dengan cara memberikan ruang untuk si pengamen menyelonjorkan kakinya dan bersedia membangunkan si pengamen di Stasiun Cikampek.

“...Sekar keluarkan trashbag dari head carriernya, ia punguti satu persatu sampah yang ia temukan di pos dua." (SYM 2:110)

Kutipan di atas menunjukan kepedulian yang dimiliki Sekar terhadap alam. Sekar sangat tidak menyukai kelakuan orang-orang yang mengotori alam. Dengan begitu, untuk mengurangi kerusakan alam yang ada ia rela memunguti sampah yang bukan miliknya demi menjaga kelestarian alam.

“... Eliza mengungkapkan bahwa masyarakat Noari dan Arabe tidak terlalu bergantung dengan uang. Uang hanya mereka miliki seperlunya sebagai alat tukar yang formal. Akan lebih bermanfaat jika kita memberikannya dalam bentuk alat produksi. Seperti misal pisau, parang, mesin jahit, dan sebagainya. "(SYM 2:92)

Kutipan diatas menggambarkan bentuk kepedulian Eliza terhadap kesejahteraan masyarakat dalam jangka panjang, bukan sekadar jangka pendek dengan pemberian uang.

2. Tanggung Jawab

a. Nilai Rasa Memiliki 


\section{Lingua Rima: Jurnal Pendidikan Bahasa dan Sastra Indonesia \\ Vol. 10 No. 2 Juli 2021 \\ http://jurnal.umt.ac.id/index.php/lgrm}

Nilai rasa memiliki dalam novel ini, di tunjukan pada tokoh El yang sangat mencintai Sekar. El memiliki sikap kepekaan yang mewujudkan rasa cintanya kepada Sekar dengan berbagai cara yang dilakukan agar dapat melihat kekasihnya tersenyum bahagia.

“assalamualaikum, Non:)

Iya bener yang ada dipikiranmu, kurir yang nganter buku tadi adalah orang yang paling merindukanmu sedunia, tuanmu, bung'mu, bosmu, panitiamu, pasanganmu melawan, seorang urakan yang siap menjagamu dari siapa-siapa, Bapak dari anak-anakmu di desa kelak, laki-laki yang menerima serantang nasi yang kau antar ke sawah desa kelak. Aku, El, kesayanganmu." (SYM 1: 257)

Kutipan di atas diambil dari novel Sepasang yang Melawan 1, menggambarkan bagaimana bentuk tanggung jawab El sebagai kekasih, yang selalu membuat Sekar bahagia dengan segala keunikan tingkah lakunya, yang tidak ingin membuat kekasihnya bersedih, dan merasa kesepian.

“...El mengalungkan tangan kirinya ke pundak Sekar, memastikan kekasihnya ada yang melindungi.” (SYM 2:42)

Kutipan di atas menceritakan El sebagai seorang kekasih yang melindungi kekasihnya yang sedang merasa ketakutan. Hal ini membuktikan rasa memiliki dan bentuk tanggung jawab sebagai seorang kekasih untuk melindungi pasangannya.

b. Disiplin

Nilai disiplin dapat diterapkan di mana saja, nilai disiplin ini menunjukan perilaku tertib dan patuh pada berbagai ketentuan dan peraturan.

“...El dan sekar pun menyusulnya tak lama setelah mereka gelar sembahyang Dzuhur dan Ashar yang mereka jamak” (SYM 1: 386)

Kutipan di atas diambil dari cerita novel Sepasang yang Melawan 1 yang menggambarkan nilai disiplin, yaitu sebagai bentuk tanggung jawab seorang muslim, walaupun mereka sedang mendaki gunung sekalipun.

c. Empati

Nilai empati diperlihatkan oleh tokoh di dalam Dwilogi Novel Sepasang Yang Melawan, bagaimana tokoh-tokoh ini memahami kehidupan orang lain. Hal ini dapat dibuktikan dengan kutipan-kutipan berikut:

“...Dia gak mau beli akua, dia keukeuh bilang bahw atanah, air, udara itu gratis. Dia ga mau makan di fast food-fast food ala Amerika dan kebarat-baratan, dia gak mau dateng ke tempat-tempat yang menciptakan jarak, menciptakan pagar, yang memperjelas beda si kaya dan si miskin. Dia gak mau dateng ke tempat yang orang miskin ga bisa dateng. Dia 


\section{Lingua Rima: Jurnal Pendidikan Bahasa dan Sastra Indonesia \\ Vol. 10 No. 2 Juli 2021 \\ http://jurnal.umt.ac.id/index.php/lgrm}

ga mau makan yang orang miskin ga bisa makan. Dia ga mau beli barang yang orang miskin ga bisa beli" (SYM 1:243)

Kutipan di atas diambil dari cerita novel Sepasang yang Melawan 1, menggambarkan bagaimana sikap El yang memiliki nilai empati pada masyarakat kalangan bawah. El tidak ingin merasakan kesenangan sendiri dan tidak ingin melihat kesusahan orang lain. Maka, melalui kutipan tersebut pembaca dapat menemukan nilai-nilai empati terhadap sesama tanpa harus memandang perbedaan kasta.

"ini," Rama memberikan sebuah coklat kepada Sekar. Buat teman baca buku," kata Rama pada Sekar yang langsung kembali duduk di mejanya membaca buku. ”(SYM 1: 242)

Kutipan di atas menggambarkan sikap empati Rama, ia menghibur Sekar saat ia merasakan kegundahan dalam hatinya yang selalu memikirkan El, yaitu dengan cara Rama memberikan coklat kesukaan Sekar.

“...Maria datang terlambat, matanya sembab. Eliza mengajaknya menyingkir dari temantemannya. Maria bercerita, semalam Bapaknya memukuli ibunya.” (SYM 2:196)

Kutipan di atas menunjukkan rasa empati yang dimiliki Eliza terhadap Maria. Rasa empati yang dimiliki Eliza yakni ketika ia memahami dan memberikan kesempatan Maria untuk mencurahkan isi hatinya, dengan tujuan Maria tidak menanggung beban ini sendiri.

3. Keserasian Hidup

a. Nilai Keadilan

Nilai keadilan yang ditemukan dalam Dwilogi Novel Sepasang yang Melawan adalah nilai keadilan bagaimana menggunakan hak dan kewajiban secara benar dan seimbang, berikut adalah kutipannya:

"Bagaimana bisa Anda melakukan itu? Anda tidak punya hak untuk mengusir saya hanya karena penampilan saya di luar standar yang bisa memuaskan Anda. Tidak bisa!"

El keluar. Kebisuan kelas tercipta kembali beberapa saat.

Tiba-tiba sekar berdiri dan berjalan ke arah pintu. Ia berdiri menahan langkahnya di tempat yang sama dengan saat tadi ia memohon untuk masuk. Sekar membelakangi pintu, lalu membungkukkan badan ke arah Bu Ani.

"Maaf, Bu. Saya juga terlambat. Permisi," kata sekar sebelum ia melangkah meninggalkan kelas.”(SYM 1:4)

Kutipan di atas diambil dari novel Sepasang yang Melawan 1 yang menggambarkan nilai keadilan antara hak dan kewajiban secara benar. Kutipan tersebut menyampaikan bagaimana bentuk keadilan yang di tunjukkan pada El dan Sekar. Bahwa dalam kutipan tersebut bertujuan agar kita sebagai manusia tidak boleh membeda-bedakan atau menilai Nilai-Nilai Sosial dalam Dwilogi Novel Sepasang yang Melawan Karya Jazuli Imam (Pendekatan Sosiologi Sastra) 


\section{Lingua Rima: Jurnal Pendidikan Bahasa dan Sastra Indonesia \\ Vol. 10 No. 2 Juli 2021 \\ http://jurnal.umt.ac.id/index.php/lgrm}

orang dari luarnya saja, belum tentu dengan tampilan yang urakan malah justru mereka yang memiliki hati nurani.

“...Tanpa permisi dan argumentasi, Bapak Pius datang ke pos jaga melewati para penjaga. Ia bangunkan Lana yang tertidur sebab sedari sore terduduk di pojok kantor layaknya seorang saparatis yang tertangkap tentara. Bapak Pius langsung membawa pulang lana begitu saja." (SYM2:182)

“...entah karena apa. Atau mungkin sebab mereka sadar bahwa alasan ditangkapnya Lana terlalu sepele, yaitu sebuah buku.” (SYM 2:183)

Kutipan di atas menggambarkan pembelaan yang dilakukan Bapak Pius kepada Lana, karena Bapak Pius tahu kalau hal itu bukan sebuah kesalahan. Lana ini adalah seorang relawan di Noari Papua. Lana selalu membantu anak-anak dan warga Papua baik pendidikan maupun kesejahteraan masyarakat. Nilai sosial yang terkandung yaitu kesadaran Bapak Pius untuk melawan ketidak adilan. Bapak Pius menyadari bahwa hal yang dilakukan Lana bukan sebuah kesalahan, untuk itu Bapak Pius tidak terima kalau hal ini menjadi sebuah masalah besar.

“...Anak-anak besok kalau ada masalah dengan sepatu atau tas kalian. Jangan khawatir. Mulai besok ibu berangkat ke sekolah tidak memakai sepatu, tidak bawa tas juga. Ibu nyeker dan pakai noken.” Kata Eliza. (SYM 2:198)

Kutipan di atas, menggambarkan betapa adilnya sikap Eliza, ia tidak ingin melihat semangat belajar anak-anak luntur karena permasalahan sepatu dan tas yang mereka pakai. Oleh karena itu Eliza mengurungkan niatnya untuk sama-sama tidak memakai sepatu juga saat mengajar.

b. Toleransi

Nilai toleransi adalah sebuah sikap yang dapat menghargai suatu pendirian, pendapat, pandangan, kepercayaan, ataupun yang lainnya yang berbeda dengan pendirian sendiri. Dalam hal penelitian ini dapat dibuktikan dengan kutipan sebagai berikut:

“...Pagi itu waktu menunjukkan pukul 09.30 WIB. Cukup lama Sekar menunggu sebab angkutan tidak berlangsung berjalan. "Nunggu penumpang liyane," begitu kata si bapak supir. Sekar bisa mengerti, sebab memang jumlah angkutan dan penumpang disini tidak sebanyak di kotanya- Bandung- atau kota-kota lain." (SYM 2:90)

Kutipan di atas diambil dari novel Sepasang yang Melawan 2, nilai toleransi diberikan Sekar kepada bapak supir yang sudah mau menunggu angkutan yang ngetem. Sekar telah bersikap sabar dan memaklumi bapak supir agar penumpang yang dibawa lebih banyak lagi. 


\section{Lingua Rima: Jurnal Pendidikan Bahasa dan Sastra Indonesia \\ Vol. 10 No. 2 Juli 2021 \\ http://jurnal.umt.ac.id/index.php/lgrm}

"Lana, yang meski seorang muslim, ia kerap ikut menghadiri misa di gereja seperti pagi itu." (SYM 2: 220)

Kutipam di atas adalah nilai toleransi beragama yang dimiliki Lana, ia memahami bahwa sebagian besar warga Noari beragama kristen, tetapi cara ia menghargainya yaitu dengan menghadiri misa setiap hari minggu.

c. Kerjasama

Nilai kerjasama merupakan suatu kegiatan yang dikerjakan secara bersama-sama. kegiatan ini penting dilakukan karena sewaktu-waktu manusia sebagai makhluk sosial memerlukan bantuan orang lain untuk mencapai tujuan bersama. Kegiatan ini dapat dilakukan dimana saja dan oleh siapa saja. Kegiatan kerjasama sangat dibutuhkan karena untuk mempererat tali silaturahmi juga suatu kegiatan yang dikerjakan dapat diselesaikan dengan cepat dan mudah. Dalam hal ini dapat dibuktikan dengan kutipan sebagai berikut:

“...Aku pasrahin Lifewalker untuk Merapi dan Merbabu ya. Nanti aku kirim gambargambar desainnya setiap bulan lewat email. Selebihnya kamu ngerti lah harus gimana. Keuntungan kamu ambil lima puluh persen, lima puluh persennya kamu kirim ke rekeningku," Kata El pada Indra kawan baiknya di kontrakkan. (SYM 1: 347)

Kutipan di atas diambil dari novel Sepasang yang Melawan \#1 yang menggambarkan nilai kerjasama yang dilakukan oleh El dan Andri untuk mengurusi usaha kaos yang dimiliki El. Dari kutipan di atas telihat jelas bentuk kerjasamanya, yaitu mereka saling membantu untuk kesuksesan Lifewalker saat El sedang tidak berada di Jogja.

“...Menjelang sore, El mencari ikan di danau sementara Sekar memasak nasi.”(SYM 2:20)

Kutipan di atas menggambarkan suasana yang terjadi ketika berada di Gunung menceritakan kekompakkan yang terjadi antara El dan Sekar. Pada saat di Gunung pun mereka tetap saling melaksanakan tugas yang menjadi bagiannya masing-masing. Bentuk kerjasama yang mereka jalankan adalah tradisi para pendaki, yaitu harus saling bahumembahu agar meringankan dan mengefisienkan waktu.

“...Malam semakin beranjak. Penerbitan buku yang telah disetujui Sekar baru sekedar rencana. Mas Dewo mengungkapkan realisasi terdekat masih sekitar beberapa bulan ke depan." (SYM 2:88)

Kutipan di atas menggambarkan bahwa Sekar siap menjalankan kerjasama yang ditawarkan Mas Dewo untuk menjadi bagian dari rekan kerjanya, walaupun sebetulnya penerbitan buku ini baru rencana semata yang disusun oleh Mas Dewo, tetapi Sekar siap Nilai-Nilai Sosial dalam Dwilogi Novel Sepasang yang Melawan Karya Jazuli Imam (Pendekatan Sosiologi Sastra) 


\section{Lingua Rima: Jurnal Pendidikan Bahasa dan Sastra Indonesia \\ Vol. 10 No. 2 Juli 2021 \\ http://jurnal.umt.ac.id/index.php/lgrm}

siaga untuk menjalankannya. Kutipan di atas dapat pula dikaitkan dengan sikap tolongmenolong, karena sikap tolong-menolong inilah yang membuat Sekar untuk ikut serta dalam kerjasama dalam usaha yang dijalankan oleh Mas Dewo.

“...Naskah Bang Safri,” Sekar menyimpulkan.

"Wahhh!!! Udah ada yang nyunting, belum? Aku mau dong, Mas. Kebanggaan banget ngedit buku pejalan gila itu," kata Sekar.

"Emang tugasmu kok. Yang lain ada garapan masing-masing," ucap Mas Dewo pada Sekar.

"Siaaaap!!!" Sekar bersemangat.

"Layoutu aman?” Mas Dewo bertanya pada semua.

“Aman, Mas. Aku yang garap,” sahut Wiji. (SYM 2:145)

Kutipan di atas adalah gambaran percakapan yang terjadi di kantor penyuntingan, saat itu karyawan yang bekerja di Djelajah Pustaka saling bekerjasama sesuai dengan tugasnya masing-masing. Hal ini menunjukkan bentuk kerja sama yang dilakukan oleh pegawai Djelajah pustaka untuk menyelesaikan pekerjaannya sesuai dengan tugas dan tanggung jawabnya masing-masing.

d. Demokrasi

Demokrasi pada Dwilogi Novel Sepasang yang Melawan, dapat dilihat pada novel Sepasang yang Melawan 2 yaitu ditunjukkan oleh tokoh Lana dan Eliza. Mereka memiliki pemikiran yang sama yaitu melakukan protes kepada pemerintah yang akan membuka lahan pertanian di tanah Papua. Mereka tidak setuju kalau masyarakat Papua harus menggantikan pangan mereka menjadi nasi.

“...Jika kamu bertanya tentang sikap, maka sikap saya; saya menolak pembukaan lahan untuk padi. Anda perlu tahu bahwa saya terlibat mendukung kawan-kawan lokal di Muting melawana sawah, sawit, karet, yang menggusur pohon-pohon sagu, menguras air, merubah budaya lokal dan segala jenis degeasi lain, atas nama uang, pembangunan, atau apapun argumentasi di balik kerakusan orang kota." (SYM 2:177)

Kutipan di atas menggambarkan bagaimana Eliza membela masyarakat Papua dan menentang pemerintah. Sikap Eliza ini adalah melawan. Eliza mendukung masyarakat Papua untuk menolak pembukaan lahan penanaman padi, karena ia menganggp bahwa hal ini sudah menjadi budaya dan kebiasaan masyarakat Papua mengkonsumsi pangan pokok dengan sagu bukan nasi, maka sikap Eliza ini berani mengungkapkan pendapatnya terhadap tindakan pemerintah yang akan menggusur tanaman sagu menjadi tanaman padi dll.

\section{SIMPULAN DAN SARAN}

Nilai-Nilai Sosial dalam Dwilogi Novel Sepasang yang Melawan Karya Jazuli Imam (Pendekatan Sosiologi Sastra) 


\section{Lingua Rima: Jurnal Pendidikan Bahasa dan Sastra Indonesia \\ Vol. 10 No. 2 Juli 2021 \\ http://jurnal.umt.ac.id/index.php/lgrm}

Berdasarkan hasil analisis mengenai nilai-nilai sosial pada Dwilogi Novel Sepasang yang Melawan karya Jazuli Imam disimpulkan bahwa nilai sosial yang terdapat dalam dwilogi novel tersebut yaitu nilai pengabdian, nilai tolong-menolong, nilai kekeluargaan, nilai kesetiaan, nilai kepedulian, nilai rasa memiliki, nilai disiplin, nilai empati, nilai keadilan, nilai toleransi, nilai kerjasama, dan nilai demokrasi. Nilai-nilai sosial yang terkandung di dalam dwilogi novel ini penting untuk ditanamkan di dalam kehidupan masyarakat, karena banyak memberikan nilai kehidupan, kemanusiaan, kebebasan alam, dan lain sebagainya yang baik bagi para pembacanya. Oleh karena itu, penelitian ini telah membahas tentang nilai-nilai sosial terhadap Dwilogi Novel Sepasang yang Melawan karya Jazuli Imam. Maka, pembaca dapat mengembangkan penelitian ini dengan meneliti aspek lain seperti pendidikan cinta lingkungan, karena dalam dwilogi novel ini banyak aspek pendidikan cinta lingkungan yang dapat dikaji lebih lanjut.

\section{E. DAFTAR PUSTAKA}

Cahyani, I., \& Rahmayanti. 2020. Nilai-Nilai Sosial dalam Novel Untukmu Imam Rahasiaku Karya Maylan Kokonoka. Jurnal Stilistika, Vol 5 No 2 PP 157-167.

Imam, J. 2014. Sepasang Yang Melawan \#1. Yogyakarta: Djelajah Pustaka.

Imam, J. 2017. Sepasang Yang Melawan \#2. Yogyakarta: Djelajah Pustaka.

Irma, C. N. 2017. Pendekatan Sosiologi Sastra dan Nilai-Nilai Pendidikan dalam Novel Punakawan Menggugat Karya Ardian Kresna. Jurnal Bindo Sastra, Vol 1 No 1

Nasution, W. 2016. Kajian Sosiologi Sastra Novel Dua Ibu Karya Arswendo Atmowiloto: Suatu Tinjauan Sastra. Jurnal Bahasa STKIP. Vol 4 No 1 PP 14-27.

Oktaviyanti, R. 2016. Implementasi Nilai-Nilai Sosial dalam Membentuk Perilaku Sosial Siswa SD. Journal of Primary Education. Vol 5 No 2 PP 77-84.

Saputra, W., Atmazaki, \& Abdurahman. 2012. Nilai-Nilai Sosial dalam Novel Bukan Pasar Malam Karya Pramoedya Ananta Toer. Jurnal Pendidikan Bahasa dan Sastra Indonesia, 409-417.

Solihati, N., Hikmat, A., \& Hidayatullah, S. 2016. Teori Sastra. Jakarta: Uhamka Press.

Trisnawati. 2018. Analisis Nilai Moral dan Nilai Sosial pada Kumpulan Cerpen Karya Ahmad Tohari sebagai Upaya Pemilihan Bahan Pembelajaran pada Siswa Kelas $X$ SMAN 5 Pandeglang. Jurnal Artikula. Vol 1 No 1 PP 17-28.

Zubaedi. 2007. Pendidikan Berbasis Masyarakat. Yogyakarta: Pustaka Pelajar. 